\title{
Life Histories of Subarctic Ants
}

\author{
JÜRGEN HEINZE ${ }^{1}$
}

(Received 29 June 1992; accepted in revised form 5 October 1992)

\begin{abstract}
Ant species belonging to seven genera occur in habitats near the tree line in the Northern Hemisphere. An analysis of colony founding strategies suggests that in addition to physiological cold resistance, behavioral and sociometric adaptations might be important for survival and propagation of ants in subarctic biomes.
\end{abstract}

Key words: polygyny, budding, ants, Formicidae, Leptothorax

RÉSUMÉ. Des espèces de fourmis appartenant à sept genres vivent dans des habitats aux environs de la limite d'arbres. Une analyse des stratégies de fondation des sociétés suggère que, en plus d'une résistance physiologique au froid, des adaptations sociométriques et comportementales pourraient être importantes pour la survie et la propagation dans les biomes subarctiques.

Mots clés : polygynie, bouturage, fourmis, Formicidae, Leptothorax

\section{INTRODUCTION}

The ant fauna of boreal and alpine biomes consists of a monotonously small number of species and thus has been given little attention by myrmecologists (Gregg, 1972; Francoeur, 1983; Nielsen, 1987). Nevertheless, ants locally occur in high densities even near and beyond the tree line, suggesting that they play an important role in subarctic ecosystems, both as prey and predators (Nielsen, 1987).

Boreal ants have to cope with harsh environmental conditions, such as extremely low temperatures and long winters, but little is known about how they are adapted to life in the cold. Ants hibernate in a dense cluster of workers, queens, and in some species also larvae, and only few workers are found solitarily near the nest entrance and in other parts of the colony (Eidmann, 1943). Nest cavities of Leptothorax, subgenus Leptothorax (s.str.), may be partially filled with ice crystals, and even under protective snow cover temperatures in the nest may fall below $-20^{\circ} \mathrm{C}$ (Berman $e t$ al. , 1982). Hibernating Leptothorax acervorum from Siberia are known to survive temperatures of $-40^{\circ} \mathrm{C}$ by accumulating anti-freeze polyols (Leyrikh, 1989).

Recently it was suggested that in addition to physiological adaptations, changed life history strategies might facilitate the propagation of boreal ants (Heinze, 1991).

In the following, records of ants from areas near the tree line and data on their colony structures and colony founding strategies are summarized. Possible interrelations between life history traits and the occurrence in areas with long and cold winters are examined.

\section{RECORDS OF ANTS NEAR THE TREE LINE}

According to the sparse data scattered in the literature and from personal observation, species of seven genera of ants live near the tree line in northern Eurasia and America (Table 1), three belonging to the subfamily Formicidae (Camponotus, Formica, Lasius) and four to the Myrmicinae (Formicoxenus, Harpagoxenus, Leptothorax, Myrmica). All species are common throughout boreal coniferous forests, but only few reports document their occurrence beyond the tree line in tundra habitats (e.g., Gregg, 1972). The ants ranging farthest north are taxa of Leptothorax (s.str.): a colony of Leptothorax "muscorum" was collected $80 \mathrm{~km}$ north of the tree line on Richards Island, N.W.T. (Brown, 1955); Arnoldi (1968, 1969) lists L. acervorum as the only species occurring in Russian tundra; and at least two Leptothorax species are common in tundra habitats in Quebec (Francoeur, 1983; pers. obs.). Of the other species, at least Camponotus herculeanus most probably does not advance far into treeless areas, as it requires wood as nesting material. Ants are completely absent from Greenland and Iceland today, but fossil Camponotus and Formica were found in the Plio-Pleistocene Kap K $\phi$ benhavn Formation in northernmost Greenland (Böcher, 1989).

\section{LIFE HISTORIES OF BOREAL ANTS: LEPTOTHORAX}

With a total length of less than $5 \mathrm{~mm}$, Leptothorax (s.str.) are by far the smallest boreal ants and also have the smallest colonies. Typical nests contain from a few dozen to hundreds of workers (Fig. 1) and are built in cavities in decaying twigs, moss, or bark, or under stones.

A comparative analysis of colony and population structures of leptothoracine ants from various biomes suggests a correlation between life in northern habitats and optional dependent colony founding strategies. The majority of the approximately 300 Leptothorax species live in temperate or subtropic biomes, such as the Mediterranean, the Near East, or the southern United States. In most southern species (subgenera Myrafant, Temnothorax, Macromischa, etc.) nests are obligatorily monogynous, i.e., they contain only a single inseminated egg-laying queen. New colonies are founded independently by young queens, which isolate themselves in small cavities directly after mating in midsummer (Table 2; see also Buschinger, 1968, 1974; Plateaux, 1970). In contrast, in colonies of all species belonging to the boreal subgenus Leptothorax (s.str.) and in many boreal and alpine L. (Myrafant) several inseminated queens may be present (e.g., Buschinger, 1968; Alloway et al., 1982; Heinze and Buschinger, 1988; Stille et al., 1991). Solitary founding queens have rarely been found. Direct observations and

\footnotetext{
'Theodor-Boveri-Institut für Biowissenschaften, Zoologie II, Am Hubland, D-97074 Würzburg, F.R. Germany

(CThe Arctic Institute of North America
} 
TABLE 1. Species list of ants from boreal habitats near the tree line ${ }^{\dagger}$

\begin{tabular}{|c|c|c|c|c|c|c|c|c|}
\hline & Ala & $\mathrm{Ch}$ & NQ & MLC & MW & FM & NR & NESib \\
\hline \multicolumn{9}{|l|}{ Myrmica } \\
\hline alaskensis ${ }^{2}$ & $x$ & $x$ & $x$ & $x$ & & & & \\
\hline brevispinosa & $x$ & & & & & & & \\
\hline lobicornis $1 ?$ & & & & & & $x$ & $x$ & $(x)$ \\
\hline rubra ${ }^{2}$ & & & & & & $x$ & $x$ & $x$ \\
\hline ruginodis ${ }^{3}$ & & & & & & $x$ & $x$ & $x$ \\
\hline c.f. brevinodis & & & & & & & & $x$ \\
\hline sulcinodis ${ }^{3}$ & & & & & & $x$ & $x$ & $x$ \\
\hline rugulosa $a^{2}$ & & & & & & & & $x$ \\
\hline bergi & & & & & & & & $x$ \\
\hline \multicolumn{9}{|l|}{ Leptothorax (s.str.) } \\
\hline acervorum ${ }^{2}$ & $x$ & $x$ & $x$ & & & $x$ & $x$ & $x$ \\
\hline cf. canadensis ${ }^{2}$ & $x$ & $x$ & $\times$ & $x$ & $x$ & & & \\
\hline sp. $A^{2}$ & & & & $x$ & & & & \\
\hline wilsoni ${ }^{4}$ & & & & $x$ & & & & \\
\hline \multicolumn{9}{|c|}{ Leptothorax (Myrafant) } \\
\hline c.f. tuberum ${ }^{3}$ & & & & & & & & $x$ \\
\hline \multicolumn{9}{|l|}{ Formicoxenus } \\
\hline quebecensis ${ }^{4}$ & & & & $x$ & & & & \\
\hline nitidulus 4 & & & & & & $x$ & & \\
\hline \multicolumn{9}{|l|}{ Harpagoxenus } \\
\hline canadensis 4 & & & & $x$ & & & & \\
\hline sublaevis ${ }^{4}$ & & & & & & $x$ & & \\
\hline \multicolumn{9}{|l|}{ Lasius } \\
\hline flavus ${ }^{3}$ & & & & & & $x$ & & \\
\hline \multicolumn{9}{|l|}{ Formica } \\
\hline neorufibarbis ${ }^{2}$ & $x$ & $x$ & $x$ & & $x$ & & & \\
\hline subnuda ${ }^{4}$ & $x$ & & $x$ & & & & & \\
\hline whymperi & $x$ & & & & & & & \\
\hline podzolica & $x$ & & & & & & & \\
\hline fusca $^{3}$ & $x$ & & & & & & & $x$ \\
\hline lemani ${ }^{2}$ & & & & & & $x$ & $x$ & $x$ \\
\hline gagatoides $^{3}$ & & & & & & $x$ & $x$ & $x$ \\
\hline exsecta ${ }^{2,4}$ & & & & & & $x$ & & $x$ \\
\hline uralensis $^{2,4}$ & & & & & & $x$ & $x$ & \\
\hline sanguinea ${ }^{2,4}$ & & & & & & $x$ & & $x$ \\
\hline truncorum $^{2,4}$ & & & & & & $x$ & $x$ & \\
\hline picea & & & & & & & $x$ & $x$ \\
\hline lugubris $2,4^{*}$ & & & & & & $x$ & $x$ & $x$ \\
\hline aquilonia 2,4 & & & & & & $x$ & $x$ & $x$ \\
\hline \multicolumn{9}{|l|}{ Camponotus } \\
\hline herculeanus ${ }^{1}$ & $x$ & $x$ & $x$ & $x$ & $x$ & $x$ & $x$ & $x$ \\
\hline saxatilis & & & & & & & & $x$ \\
\hline japonicus & & & & & & & & $x$ \\
\hline
\end{tabular}

†Ala: central and interior Alaska (Nielsen, 1987; D. Ortius, pers. comm. 1991); Ch: Churchill, Manitoba (Gregg, 1972); NQ: Nouveau Québec (Francoeur, 1983); MLC: Mt. du Lac des Cygnes, Québec; MW: Mt. Washington, New Hampshire; FM: Finnmark, Norway (Collingwood, 1979; Holgersen, 1940); NR: tundra and forest-tundra of northern Russia (Arnoldi, 1968); NESib: northeastern Siberia (Kolyma Mts., Bolshoi Annachag; Berman et al., 1980; Zhigulskaya and Berman, 1975). Colony founding strategies are indicated as follows (based on numerous references, e.g., Collingwood, 1979; Rosengren and Pamilo, 1983; Buschinger, 1974): 'obligatorily monogynous, colonies founded by solitary queens; ${ }^{2}$ queen adoption and budding likely or observed; ${ }^{3}$ polygyny observed; ${ }^{4}$ social parasite or guest ant.

*The social structure of $\boldsymbol{F}$. lugubris colonies shows geographic variation - nests from Central Europe are polygynous, but nests from Finland are mainly monogynous (Pamilo et al., 1992).

seasonal fluctuations of colony structures in Leptothorax (s.str.) suggest that while some queens disperse and attempt independent colony founding immediately after mating, others are adopted into established nests.

In Leptothorax muscorum, $L$. acervorum from European populations, L. (M.) curvispinosus, and others, queen adoption leads to secondary polygyny, i.e., several queens lay eggs within a single colony. Though egg-laying rates of

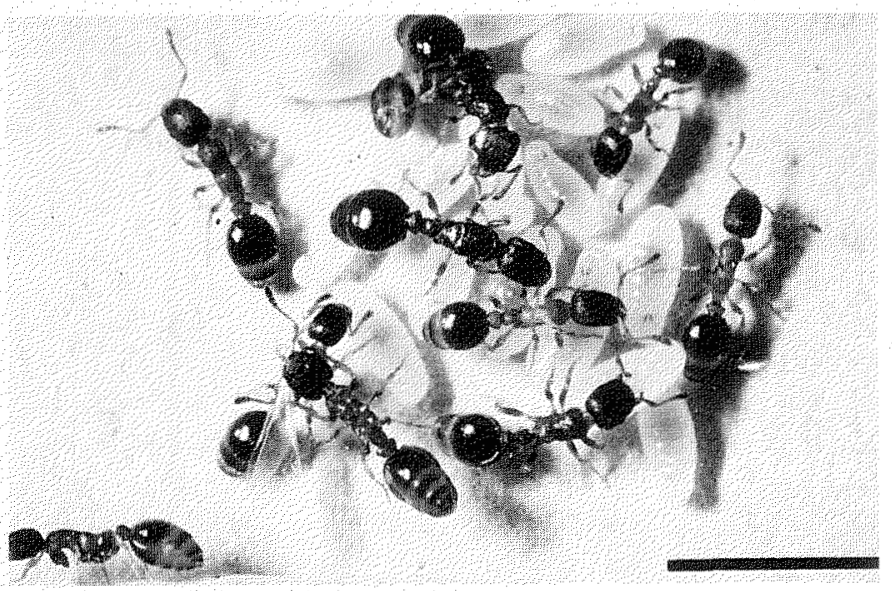

FIG. 1. Laboratory nest of Leptothorax sp. A from Quebec. Typical colonies of this ant consist of only a few dozen workers and may contain several queens. The large individual on top of the brood pile is a queen. The scale equals $5 \mathrm{~mm}$.

TABLE 2. Colony structure (see Table 1) in ants of the genus Leptothorax from various habitats ${ }^{\dagger}$

\begin{tabular}{|c|c|c|c|}
\hline Subgenus & Species & $\begin{array}{c}\text { Social } \\
\text { organization }\end{array}$ & Geographical range \\
\hline \multirow{14}{*}{$\begin{array}{l}\text { Temnothorax } \\
\text { Myrafant }\end{array}$} & recedens & 1 & Mediterranean \\
\hline & $\begin{array}{l}\text { ambiguus } \\
\text { curvispinosus }\end{array}$ & $\begin{array}{l}2 \\
2\end{array}$ & eastern North America \\
\hline & exilis & 1 & Mediterranean \\
\hline & flavicornis & 3 & Mediterranean? \\
\hline & interruptus & 3 & Central Europe, Alps \\
\hline & longispinosus & 2 & eastern North America \\
\hline & lichtensteini & 1 & Mediterranean \\
\hline & melas & 1 & Corsica \\
\hline & nigriceps & 1 & Central Europe \\
\hline & nylanderi & $1 / 3$ & $\begin{array}{l}\text { Central Europe, } \\
\text { Mediterranean }\end{array}$ \\
\hline & parvulus & 1 & Mediterranean \\
\hline & rudis & 1 & California \\
\hline & tuberum & 3 & Central Europe, Alps \\
\hline & unifasciatus & 1 & $\begin{array}{l}\text { Central Europe, } \\
\text { Mediterranean }\end{array}$ \\
\hline \multirow{9}{*}{$\begin{array}{l}\text { Macromischa } \\
\text { Leptothorax }\end{array}$} & allardycei & 1 & Florida \\
\hline & acervorum & 2 & $\begin{array}{l}\text { boreal Eurasia, } \\
\text { North America }\end{array}$ \\
\hline & cf. canadensis & 2 & boreal North America \\
\hline & crassipilis & 3 & alpine North America \\
\hline & gredleri & 2 & Central Europe \\
\hline & muscorum & 2 & boreal Eurasia \\
\hline & retractus & 3 & boreal North America \\
\hline & sp. A & 2 & boreal North America \\
\hline & sphagnicolus & 2 & boreal North America \\
\hline
\end{tabular}

tData from Buschinger (1968, 1974), Heinze and Buschinger (1988), Espadaler et al. (1984), Stuart and Page (1991), and unpubl. obs. $L$. (Myrafant) nylanderi is regularly monogynous, though polygynous nests have occasionally been found.

individual queens may differ significantly, there is no evidence of openly aggressive competition among nestmate queens (Bourke, 1991; Wilson, 1974; Lipski et al., 1992). In $L$. gredleri, $L$. sp. A, and $L$. acervorum from Alaska, on the other hand, one queen more or less completely monopolizes reproduction. Other inseminated queens are tolerated in the colony only as long as they do not become reproductive ("functional monogyny"; Buschinger, 1968). It was observed that nestmate queens engaged in stereotyped 
and openly aggressive interactions in early spring, resulting in the formation of rank orders. In each nest only the highest ranking queen began to lay eggs (Heinze and Smith, 1990; Heinze and Lipski, 1990; Heinze and Ortius, 1991).

In both polygynous and functionally monogynous Leptothorax (s.str.), spontaneous fractioning of colonies (budding) and queen emigration were observed in the laboratory. In Leptothorax sp.A and $L$. cf. canadensis from Quebec and New England and in L. acervorum from northern Norway and Alaska some inseminated queens left their nests directly after hibernation. Queens moved into empty nesting sites and were occasionally joined by workers from their maternal nests. The presence of very small colonies of $L$. sp.A, $L$. gredleri, and $L$. acervorum in early spring suggests that budding occurs regularly also in the field.

\section{SOCIAL ORGANIZATION OF OTHER BOREAL ANTS}

Though data on colony and population structures of boreal ants are rare, queen adoption and budding appear to be common strategies also among other boreal genera (Table 1). Many Myrmica and Formica species are facultatively polygynous, and colony budding was reported from both genera (e.g., Rosengren and Pamilo, 1983; Czechowski, 1984; Uchmański and Petal, 1982). Queen emigration is likely in Myrmica (e.g., Elmes, 1982). Though most species of Lasius (s.str.) are strictly monogynous, facultative polygyny was reported from Lasius flavus (Waloff, 1957).

A rather high percentage of boreal ants are social parasites - i.e., they depend on the help of other ant species at least during parts of their life cycles. Queens of temporary parasites, e.g., species belonging to the Formica rufa and Formica exsecta groups, invade nests of other Formica species, where they somehow eliminate the host queen. Host workers take care of the parasite's brood but are eventually replaced by the parasite queen's own workers. New nests may also arise through colony budding and nest splitting (e.g., Hölldobler and Wilson, 1990). Harpagoxenus sublaevis and $H$. canadensis are slave makers. Queens enter a Leptothorax (s.str.) nest and kill or expel all adult residents. Workers that eclose from the conquered Leptothorax pupae nurse the Harpagoxenus brood. Harpagoxenus workers are inefficient in brood care and do not forage; thus the parasites permanently depend on their hosts. New host workers are obtained in slave raids, during which Harpagoxenus workers pillage neighboring Leptothorax colonies (e.g., Hölldobler and Wilson, 1990). Formicoxenus are guest ants in the nests of Myrmica or Formica. Though they beg food from their hosts, they are typically capable of rearing their brood themselves. New colonies may be founded by budding within a host nest (Lenoir et al., 1992).

Camponotus herculeanus appears to be the only boreal ant species in which new nests are founded independently by solitary queens. Mature colonies are typically monogynous. Queens are intolerant of each other, but occasionally two or more queens may coexist in different parts of the same colony ("oligogyny"; Hölldobler, 1962). In contrast to other ants, male and female sexuals of Camponotus are reared in late summer and hibernate in their maternal nests before mating in spring or early summer (Hölldobler and Wilson, 1990). In Quebec, founding queens of Camponotus may therefore be found already in early June (pers. obs.), whereas in other species mating and colony founding takes place only in late July and August.

\section{ADAPTIVE VALUE OF DEPENDENT COLONY FOUNDING}

Generally, natural selection is thought to favor colony founding by solitary ant queens and the monopolization of reproduction by single queens (e.g., Hölldobler and Wilson, 1990). In southern ant faunas, a large percentage of species are strictly monogynous and new nests are initiated by dispersing queens immediately after mating in midsummer. Alternative strategies - queen adoption, polygyny, and budding - appear to be adaptations to special ecological conditions, such as unstable nest sites, habitat patchiness, or resource limitation (e.g., Hölldobler and Wilson, 1977, 1990; Bolton, 1986).

In six of seven boreal ant genera, independent colony founding is at least partly replaced by dependent strategies: queen adoption after mating and budding after hibernation or parasitic invasion of host species colonies.

As yet it is not clear whether the surprisingly high frequency of dependent founding among boreal species is accidental or causally connected with life in the cold. Several species of Lasius, Formica, Leptothorax, and Myrmica from temperate habitats are also facultatively polygynous, and Formica lugubris is mainly monogynous in Finland but polygynous in Central Europe (Pamilo et al., 1992). Hence, it appears unlikely that dispersal strategies changed in all these genera as an adaptation to life in boreal biomes. Rather, already existing life history traits might have favored facultatively polygynous species during the colonization of habitats near the tree line. Colony fractioning might be facilitated in boreal biomes by the comparatively simple structuring of ecosystems, in which potential nest sites have little diversity but occur in high densities. Furthermore, resource limitation and the shortness of summers in taiga and tundra might have favored species that produce few queens with a "safe" colony founding strategy rather than numerous dispersing queens with a high rate of founding failure.

In addition to budding, boreal ants might benefit also from another aspect of their changed life histories. Some Leptothorax (s.str.) queens emigrate from their nests directly after hibernation and probably attempt solitary founding in spring rather than budding. Similarly, due to the unusual rearing time of winged sexuals in Camponotus, new colonies are founded by solitary queens in spring. Due to the delay of colony founding from late summer and fall to spring, solitary hibernation is avoided and the period during which a young queen can rear her first brood is extended. In preliminary laboratory studies with Leptothorax cf. canadensis, solitarily hibernating ant workers and ants whose winter clusters were experimentally scattered suffered distinctly increased mortality (Heinze, unpubl. data). Herbers (1986) reported that polygynous colonies of Leptothorax (Myrafant) longispinosus survived winter better than 
monogynous nests. A positive effect of group size on winter mortality, probably caused by a higher resistance of clustered ants against both desiccation (Sigal and Arlian, 1982; but see Copp, 1983) and excessive moisture, might thus favor hibernation of young queens in established nests.

Further studies on hibernation strategies and colony and population structures of boreal Leptothorax (s.str.) are planned to substantiate these ideas. Data on the social organization of sub-Antarctic ants, which belong to other subfamilies (Ponerinae: Acanthoponera; Dolichoderinae: Dorymyrmex, Tapinoma) and thus have adapted convergently to cold climates, will be of special interest.

\section{ACKNOWLEDGEMENTS}

Studies on colony and population structures of nearctic ants were supported by the DFG Leibniz-Award to B. Hölldobler (Würzburg) and a DFG grant (He 1623/2-1). Thanks are due to B. Hölldobler for comments on the manuscript and to C. Peeters, Würzburg, for the French abstract. This paper was presented as a talk during the Circumpolar Ecosystems in Winter II Conference, hosted by the Churchill Northern Studies Centre, Churchill, Manitoba, and made an extraordinary experience by P.A. Scott, symposium chairman, J. Miller, executive director of the CNSC, and all participants.

\section{REFERENCES}

ALLOWAY, T.M., BUSCHINGER, A., TALBOT, M., STUART, R., and THOMAS, C. 1982. Polygyny and polydomy in three North American species of the ant genus Leptothorax Mayr (Hymenoptera: Formicidae). Psyche 89(3-4):249-274.

ARNOLDI, K.V. 1968. Zonal'nje zoogeograficheskie i ekologicheskie osobennosti mirmekofauny i naselenija murav'ev russko ravninj. Zoologicheskii zhurnal 47(8):1155-1178.

1969. Die zonalen ökologischen und zoogeographischen Besonderheiten der Myrmekofauna der Russischen Ebene. Pedobiologia 9:215-222.

BERMAN, D.I., ZHIGULSKAYA, Z.A., and LEYRIKH, A.N. 1980. Osobennosti biologii i ekologii murav'ev u verkhnego predela ikh rasprostranenija na khrebte Bol'shoi Annachag. In: Gornye tundry khrebta Bol'shoi Annachag (verkhov'e Kolymy). Novosibirsk. 110-126.

BERMAN, D.I., ZHIGULSKAYA, Z.A., and LEYRIKH, A.N. 1982. Ekologija Leptothorax muscorum (Hymenoptera, Formicidae) v basseine verkhnei Indigirki. Zoologicheskii Zhurnal 61(10):1509-1516.

BÖCHER, J. 1989. Boreal insects in northernmost Greenland: Palaeoentomological evidence from the Kap København Formation (Plio-Pleistocene), Peary Land. Fauna norvegica Ser. B 36:37-43.

BOLTON, B. 1986. Apterous females and shift of dispersal strategy in the Monomorium salomonis-group (Hymenoptera: Formicidae). Journal of Natural History 20(2):267-272.

BOURKE, A.F.G. 1991. Queen behaviour, reproduction and eggcannibalism in multiple-queen colonies of the ant Leptothorax acervorum. Animal Behaviour 42:295-310.

BROWN, W.L. 1955. The ant Leptothorax muscorum in North America. Entomological News 66:43-50.

BUSCHINGER, A. 1968. Mono- und Polygynie bei Arten der Gattung Leptothorax Mayr (Hymenoptera Formicidae). Insectes Sociaux 15(3):217-226.

1974. Monogynie und Polygynie in Insektensozietäten. In: Schmidt, G.H., ed. Sozialpolymorphismus bei Insekten. Stuttgart: Wiss. Verlagsges. m.b.H. 862-896.

COLLINGWOOD, C.A. 1979. The Formicidae (Hymenoptera) of Fennoscandia and Denmark. Klampenborg: Scandinavian Science Press Ltd.

COPP, N.H. 1983. Temperature-dependent behaviours and cluster formation by aggregating ladybird beetles. Animal Behaviour 31:424-430.
CZECHOWSKI, W. 1984. Colony fission and intraspecific contests in Myrmica laevinodis NYL. (Hymenoptera, Formicidae). Annales Zoologici 38(4):99-109.

EIDMANN, H. 1943. Die Überwinterung der Ameisen. Zeitschrift für Morphologie und Ökologie der Tiere 39(2):217-275.

ELMES, G.W. 1982. The phenology of five species of Myrmica (Hym. Formicidae) from South Dorset, England. Insectes Sociaux 29(4):548-559.

ESPADALER, X., PLATEAUX, L., and CASEVITZ-WEULERSSE, J. 1984. Leptothorax melas, n.sp., de Corse. Notes écologiques et biologiques [Hymenoptera, Formicidae]. Revue française d'Entomologie 6(3): 123-132.

FRANCOEUR, A. 1983. The ant fauna near the tree-line in northern Québec (Formicidae, Hymenoptera). Nordicana 47:177-180.

GREGG, R.E. 1972. The northward distribution of ants in North America. Canadian Entomologist 104:1073-1091.

HEINZE, J. 1991. Koloniegründung in der Kälte: Strategien von Ameisenweibchen in borealen Habitaten. Verhandlungen der Deutschen Zoologischen Gesellschaft 84:308.

HEINZE, J., and BUSCHINGER, A. 1988. Polygyny and functional monogyny in Leptothorax ants (Hymenoptera: Formicidae). Psyche 95(3-4):309-325.

HEINZE, J., and LIPSKI, N. 1990. Fighting and usurpation in colonies of the palaearctic ant Leptothorax gredleri. Naturwissenschaften 77:493-495.

HEINZE, J., and ORTIUS, D. 1991. Social organization of Leptothorax acervorum from Alaska (Hymenoptera: Formicidae). Psyche 98(2-3):227-240.

HEINZE, J., and SMITH, T.A. 1990. Dominance and fertility in a functionally monogynous ant. Behavioral Ecology and Sociobiology 27(1):1-10.

HERBERS, J.M. 1986. Effects of ecological parameters on queen number in Leptothorax longispinosus (Hymenoptera: Formicidae). Journal of the Kansas Entomological Society 59(4):675-686.

HÖLLDOBLER, B. 1962. Zur Frage der Oligogynie bei Camponotus ligniperda Latr. und Camponotus herculeanus L. (Hym. Formicidae). Zeitschrift für angewandte Entomologie 49(4):337-352.

HÖLLDOBLER, B., and WILSON, E.O. 1977. The number of queens: An important trait in ant evolution. Naturwissenschaften 64(1):8-15. 1990. The ants. Cambridge: Belknap Press of Harvard University Press.

HOLGERSEN, H. 1940. Ants of northern Norway. Troms $\varnothing$ Museums Arshefter Naturhistorisk Avd. 63(2):1-35.

LENOIR, A., ERRARD, C., FRANCOEUR, A., and LOISELLE, R. 1992. Relations entre la fourmi parasite Formicoxenus provancheri et son hôte Myrmica incompleta. Données biologiques et éthologiques (Hym. Formicidae). Insectes Sociaux 39:81-97.

LEYRIKH, A.N. 1989. Sesonnye ismenenija kholodoustoichivosti murave'ev na verkhnei Kolyme. Izvestija Akademii Nauk SSSR serija biologicheskaja 5:752-759.

LIPSKI, N., HEINZE, J., and HÖLLDOBLER, B. 1992. Social organization of three European Leptothorax species (Hym.: Formicidae). In: Billen, J., ed. Biology and evolution of social insects. Leuven: Leuven University Press. 287-290.

NIELSEN, M.G. 1987. The antfauna (Hymenoptera: Formicidae) in northern and interior Alaska. A survey along the trans-Alaskan pipeline and a few highways. Entomological News 98(2):74-88.

PAMILO, P., CHAUTEMS, D., and CHERIX, D. 1992. Genetic differentiation of disjunct populations of the ants Formica aquilonia and Formica lugubris in Europe. Insectes Sociaux 39(1):15-29.

PLATEAUX, L. 1970. Sur le polymorphisme social de la fourmi Leptothorax nylanderi (Förster). I. Morphologie et biologie comparées des castes. Annales des Sciences Naturelles, ser. 12, 12(4):373-478.

ROSENGREN, R., and PAMILO, P. 1983. The evolution of polygyny and polydomy in mound-building Formica ants. Acta Entomologica Fennica 42:65-77.

SIGAL, M.D., and ARLIAN, L.G. 1982. Water balance of the social insect Formica exsectoides (Hymenoptera, Formicidae) and its ecological implications. Physiological Zoology 55:335-366.

STILLE, M., STILLE, B., and DOUWES, P. 1991. Polygyny, relatedness and nest founding in the polygynous myrmicine ant Leptothorax acervorum (Hymenoptera; Formicidae). Behavioral Ecology and Sociobiology $28(1): 9-16$. 
STUART, R.J., and PAGE, R.E. 1991. Genetic component to division of labor among workers of a leptothoracine ant. Naturwissenschaften 78:375-377

UCHMAŃSKI, J., and PETAL, J. 1982. Long-term stability of ant colonies - A simulation model. Journal of Animal Ecology 51:349-362.

WALOFF, N. 1957. The effect of the number of queens of the ant Lasius flavus (Fab.) (Hym., Formicidae) on their survival and on the rate of development of the first brood. Insectes Sociaux 4(4):391-498.
WILSON, E.O. 1974. Aversive behavior and competition in laboratory colonies of the ant Leptothorax curvispinosus. Annals of the Entomological Society of America 67:777-780.

ZHIGULSKAYA, Z.A., and BERMAN, D.I. 1975. O zoogeograficheskom polozhenii Kolimskogo nagorja po mirmikologicheskim materialam. In: Aktualnye voprocy zoogeografii. Tesisy VI vsesojuznaja zoogeograficheskaja konferrencija, Kishinev. 82-83. 